\title{
Improving Biomedical Engineering Undergraduate Learning Through Use of Online Graduate Engineering Courses During the COVID-19 Pandemic
}

\author{
Jessica E. Nesmith, John W. Hickey, and Eileen Haase (1) \\ Biomedical Engineering, Johns Hopkins University, Baltimore, MD 21218, USA \\ (Received 20 June 2020; accepted 13 November 2020; published online 4 January 2021)
}

\begin{abstract}
In order to provide undergraduate students with a full, rich online learning experience we adapted pre-existing online content including graduate courses from Johns Hopkins University Engineering for Professionals (JHU EP) program. These online courses were designed using published methodologies and held to a high level of rigor of a Masterslevel curriculum. Adapting pre-existing online course material enabled us to more rapidly adapt to the COVID-19 shutdown of in-person education. We adapted content to meet the majority of lab-based learning objectives rather than generating self-recorded lecture material and allowing us to focus faculty time on addressing student needs. Here we discuss benefits, challenges, and methods for replicating these courses, and lessons to be applied in future offerings from this experience.
\end{abstract}

Keywords-Undergraduate education, Online teaching, Student feedback, Graduate education, Experiential learning, Rapid course adaptation, Laboratory, COVID-19, Biomedical engineering.

\section{CHALLENGE STATEMENT}

Due to the COVID-19 pandemic shutdown, we had one week to develop a solution for teaching two required hands-on wet-lab courses, Cell \& Tissue Engineering and Methods in Nucleic Acid Sequencing (Fig. S1). The specialized equipment and laboratory environment required to perform intended experiments were not possible off-campus and alternate methods of learning these skills and course objectives were

Address correspondence to Eileen Haase, Biomedical Engineering, Johns Hopkins University, Baltimore, MD 21218, USA. Electronic mail: ehaase1@jhu.edu

Jessica E. Nesmith and John W. Hickey have contributed equally to this manuscript. required. We needed to provide a total of 77 upperclass, undergraduates an online option for half-semester experiential courses designed to provide students with hands-on skills in an active learning environment.

\section{NOVEL INITIATIVE}

Our solution to this problem was to adapt existing online content, using JHU Engineering for Professionals (JHU EP) online Masters-level courses (http s://ep.jhu.edu/) (Fig. 1, Table 1) alongside published content from academic journals and websites. We chose this over simply hosting current in-person courses online to:

1. Retain active, self-paced learning style that typifies lab-based courses

2. Leverage course material that has specifically been designed for an online educational experience

3. Maintain our high standard of coursework that focuses on cutting-edge, relevant BME material

4. Focus our energy and time on providing support to undergraduate students rather than developing online content de novo

5. Provide students with multiple options for replacing original lab courses

Using pre-developed, online-formatted course content, we quickly implemented concurrent approaches to meet lab-based learning objectives without additional time and effort required by individual instructors to generate online lecture material. We surveyed our undergraduates within the first 10-14 days and iden- 
tified a number of student needs, resulting in further course adaptations (quotes from anonymous surveys):

Honestly, it's just moving too fast for me to handle right now and I'm having trouble keeping track of deadlines [and assignments].

Concepts in Immunology are very new to almost all undergrads and I have no experience with Cell $\&$ Tissue Engineering before.

I have had difficulties playing videos on chrome, firefox, and microsoft edge and Sometimes discussion papers won't open... links?

Identified student needs were classified into four basic categories: workload, instructor access, technology access, and fostering peer interactions and community. Drawing upon our experience in creating online-exclusive Master's courses we refined these courses to meet existing learning objectives while addressing student needs (Table 2). Our solutions to these needs can serve as a baseline for online course design and implementation at other institutes.
How to: Leverage Curated Pre-existing Online Content into an Appropriate Workload

A combined Cell \& Tissue Engineering/Methods in Nucleic Acid Sequencing course (re-named Cell, Tissue \& Sequencing or CTS) enrolled 50 students and used material from a similar JHU EP offering (Fig. S2, Table 3). Short, pre-recorded lectures covered topics from the original lab course. Students analyzed raw data, generated in previous semesters, to learn the process of interpreting and explaining experimental outcomes. Learning was evaluated through quizzes, discussions, and written reports.

The remaining 27 students enrolled in a pre-selected online, graduate-level course in Immunoengineering consolidated down to a half-semester (Fig. S3, Table 3) as these students were previously enrolled in the Cell and Tissue Lab course. This option was a shift in content from either lab course but offered a similar interactive self-paced format with both video and written content for knowledge transfer, and a combination of regular quizzes and a course-long group project for evaluating learning.

The material sourced from the two JHU EP program courses was developed in the last 5 years by expert faculty and instructional designers following Quality Matters professional standards to create course offerings for graduate-level, online education (h ttps://www.qualitymatters.org/). Established recorded

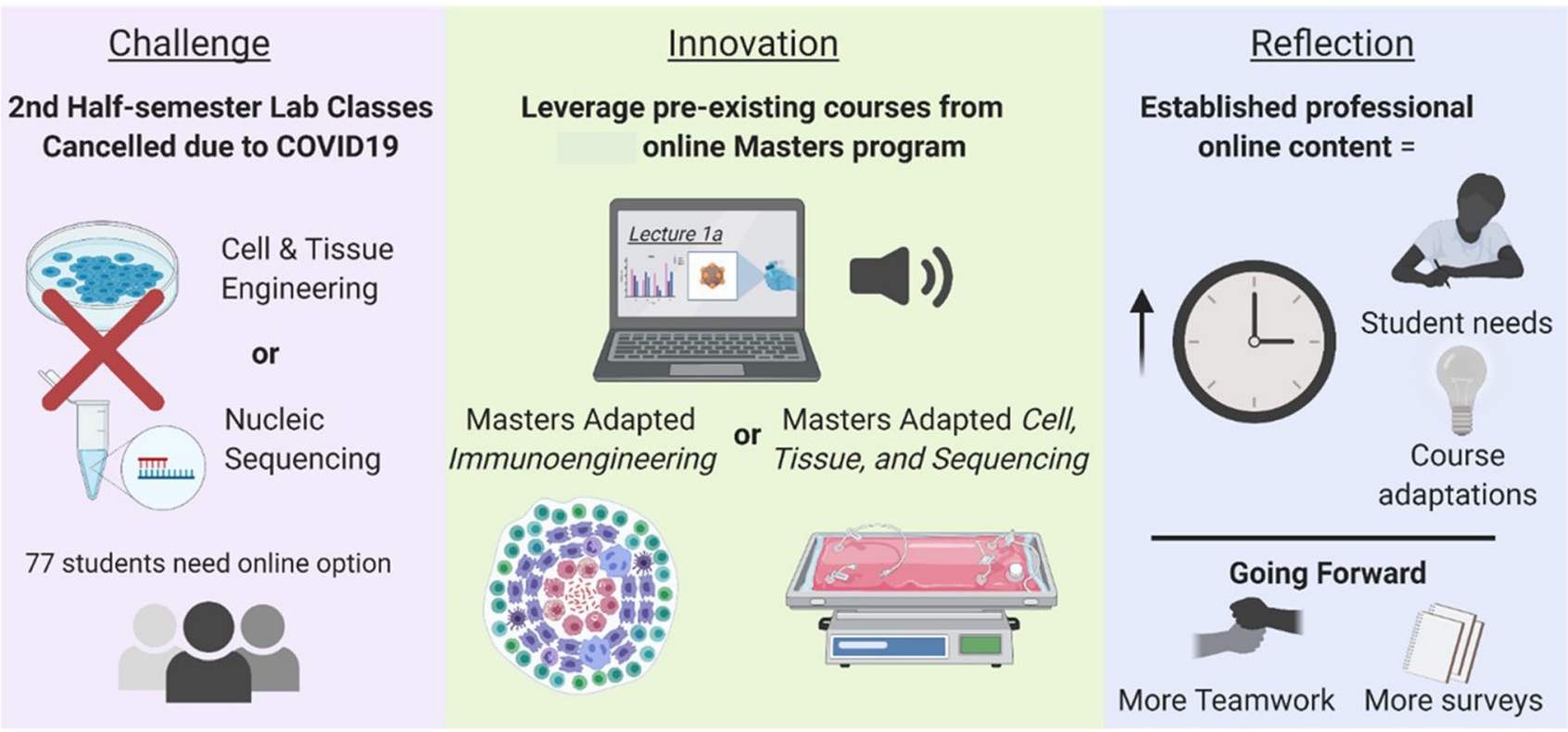

FIGURE 1. Schematic for our response to challenges presented to the Johns Hopkins Biomedical Engineering program. Briefly, 77 upper-level BME undergraduate students were supposed to take a new half semester lab course when the CovID-19 shutdown occurred. Our solution was to adapt two courses from Johns Hopkins Engineering for Professionals online masters program: Immunoengineering and Cell, Tissue, and Sequencing. Having established, high-quality, online courses enabled students to meet lab class objectives in a self-paced, active learning environment. This provided increased time for instructors to address student needs and rapidly adapt course material accordingly. We found frequent surveys useful in this process and the community building of increased teamwork activities and plan to make these core aspects of the online experience. 
TABLE 1. Comparison of the adapted undergraduate course to the traditional course taught for both Immunoengineering and Cell, Tissue, \& Sequencing courses.

\begin{tabular}{|c|c|c|c|c|}
\hline \multirow[b]{2}{*}{ Parameter } & \multicolumn{2}{|c|}{ Immunoengineering course } & \multicolumn{2}{|c|}{ Cell, Tissue, \& Sequencing Course } \\
\hline & Traditional masters & Adapted undergraduate & Traditional undergraduate & Adapted undergraduate \\
\hline \# of students & $\sim 15$ & 27 & $\sim 30$ & 50 \\
\hline \# of TAs+ instructors & 2 & 3 & 3 & 8 \\
\hline \# of modules & 14 & 13 & 4 & 6 \\
\hline \# of weeks & 14 & 7 & 7 & 7 \\
\hline \# of assignments & 12 & 6 & 6 & 6 \\
\hline Final project & Individual & Individual or group & Individual & Individual \\
\hline Grading & A scale & Pass/fail & A scale & Pass/fail \\
\hline Lecture format & pre-recorded & pre-recorded & $\mathrm{N} / \mathrm{A}$ & Live and pre-recorded \\
\hline
\end{tabular}

TABLE 2. Providing established content online to undergraduates required several adaptations to existing courses and adjustments to meet the needs of the undergraduates.

\begin{tabular}{|c|c|c|}
\hline & Immunoengineering Adaptation & Cell, Tissue, \& Sequencing Adaptation \\
\hline \multirow{3}{*}{$\begin{array}{l}\text { Instructor ac- } \\
\text { cess }\end{array}$} & Increased TA number & Increased TA number \\
\hline & Created dedicated Piazza site and moderated question forum & Assigned students to individual TA for questions \\
\hline & $\begin{array}{l}\text { Scheduled additional personal Zoom meetings for final pro- } \\
\text { ject }\end{array}$ & $\begin{array}{l}\text { Live Q\&A on online forum } \\
\text { Weekly email communication }\end{array}$ \\
\hline Workload & $\begin{array}{l}\text { Eliminated modules, homework assignments, quizzes, exam } \\
\text { questions }\end{array}$ & $\begin{array}{l}\text { Reduced written report content } \\
\text { Generous late submission policy }\end{array}$ \\
\hline \multirow{2}{*}{$\begin{array}{l}\text { Technology ac- } \\
\text { cess }\end{array}$} & Asynchronous content & Asynchronous recordings of live lectures \\
\hline & Online videos provided as file not as a link & $\begin{array}{l}\text { Provide alternate ways to earn credit for synchronous } \\
\text { participation }\end{array}$ \\
\hline \multirow{2}{*}{$\begin{array}{l}\text { Foster commu- } \\
\text { nity }\end{array}$} & Decreased workload by using built-in discussion groups & Weekly small group journal club discussions \\
\hline & Adapted individual projects to group project format & Module 2 assigned to Discussion Group \\
\hline
\end{tabular}

material within these courses is supplemented and adapted each semester with current content. JHU EP courses facilitate a group-based, self-paced, active learning environment - core purposes of laboratorybased classes. These online courses provide a wellstructured, online-friendly course framework fostering interaction with peers and the instructor team. Using entire courses and portions of these courses specifically intended for teaching online enabled our instructors to quickly provide a professional option to our undergraduate students.

We outline in Table 4 how our strategies correspond to the ABET student learning outcomes. ${ }^{1}$ Our specific laboratory course objectives state students will: (1) learn sterile laboratory techniques, (2) perform experiments using cells, (3) read and critically evaluate current papers, and (4) write a scientific publication formatted report. The coursework that we employed to meet each objective, both in the traditional in-person and adapted online courses, is summarized in Table 5. Of these, only the second objective regarding physical performance of experiments using cells remains unfeasible in off-campus or online learning, with sterile and complex equipment needed for living materials prohibitive in these formats. With such limitations to meet this learning objective, we adjusted student success evaluation to quizzes on video-based training and instruction, and formalized interactive data discussions on forums and in video meetings (Table 5). Online videos cannot replace hands-on experiences or completely address this learning objective, but this format could prove useful to implement in future in-person lab classes. It mimics "flipped classrooms" where the instructor facilitates discussion and problem solving around a topic rather than traditional lecturing. Thus, virtual labs containing pre-existing training videos and interactive online-friendly instruction could improve courses used even when social distancing is no longer necessary, as they show a clear educational benefit even without physical practice of techniques. Indeed, studies have shown students in online lab courses retain confidence in material ${ }^{2}$ and are easily able to transition to physical experiments. ${ }^{3}$ 
TABLE 3. Course structure, workload, and grading for two adapted online courses.

\begin{tabular}{|c|c|c|c|c|c|c|}
\hline \multirow[b]{2}{*}{ Requirement } & \multicolumn{3}{|c|}{ Immunoengineering Course } & \multicolumn{3}{|c|}{ Cell, Tissue, \& Sequencing Course } \\
\hline & Value & $\begin{array}{l}\text { Time ex- } \\
\text { pected }\end{array}$ & Grade & Value & $\begin{array}{l}\text { Time ex- } \\
\text { pected }\end{array}$ & Grade \\
\hline Lectures/module & 3-7 (15 min average) & $2 \mathrm{~h}$ & $\mathrm{~N} / \mathrm{A}$ & $\begin{array}{l}1 \text { live }(45 \mathrm{~min}) \\
1 \text { recorded video protocol (15-20 } \\
\text { min) }\end{array}$ & $1 \mathrm{~h}$ & $10 \%$ \\
\hline Readings/module & 1 scientific article/module & $1 \mathrm{~h}$ & N/A & 1 article and protocol $/$ module & $2-3 \mathrm{~h}$ & N/A \\
\hline Assignments & 1 per week & $2 \mathrm{~h}$ & $20 \%$ & 1 per module & $1 \mathrm{~h}$ & $65 \%$ \\
\hline Quizzes & 1 per week & $10 \mathrm{~min}$ & $5 \%$ & 2 (beginning \& end) & $2 \mathrm{~h}$ (total) & $15 \%$ \\
\hline $\begin{array}{l}\text { Project assign- } \\
\text { ment }\end{array}$ & 8 milestone assignments & $1-2 \mathrm{~h}$ & $45 \%$ & - & - & \\
\hline Discussion & $\begin{array}{l}1 \text { post and } 1 \text { response per } \\
\text { week }\end{array}$ & $30 \mathrm{~min}-1 \mathrm{~h}$ & $10 \%$ & 1 post \& response, in-person & $1-2 \mathrm{~h}$ & $10 \%$ \\
\hline Exam & halfway through material & $\begin{array}{l}90 \text { min } \\
\quad \text { allowed }\end{array}$ & $20 \%$ & - & - & \\
\hline
\end{tabular}

TABLE 4. Identification of course materials that meet group-based, self-paced, and active learning environment of laboratory courses.

\begin{tabular}{|c|c|c|c|}
\hline Design standard & $\begin{array}{l}\text { Method } \\
\text { of learn- } \\
\text { ing used }\end{array}$ & ABET student learning outcomes achieved & How this fosters ABET objective* \\
\hline $\begin{array}{l}\text { Required weekly dis- } \\
\text { cussion posts }\end{array}$ & $\begin{array}{l}\text { Group- } \\
\text { based }\end{array}$ & $\begin{array}{l}\text { Function effectively on a team; Effective com- } \\
\text { munication; Acquire \& apply new knowledge }\end{array}$ & $\begin{array}{l}\text { Students post reflections and are required to re- } \\
\text { spond to other peers' comments helping foster } \\
\text { community }\end{array}$ \\
\hline $\begin{array}{l}\text { Group term-long pro- } \\
\text { jects }\end{array}$ & $\begin{array}{l}\text { Group- } \\
\text { based }\end{array}$ & $\begin{array}{l}\text { Function effectively on a team; Effective com- } \\
\text { munication; Establish goals \& meet objec- } \\
\text { tives }\end{array}$ & $\begin{array}{l}\text { Students required to collaborate to solve current } \\
\text { challenges in field by applying content learned }\end{array}$ \\
\hline $\begin{array}{l}\text { Course modules are } \\
\text { pre-created and to- } \\
\text { pic-oriented }\end{array}$ & $\begin{array}{l}\text { Self- } \\
\text { paced }\end{array}$ & $\begin{array}{l}\text { Acquire \& apply new knowledge; Identify and } \\
\text { solve complex engineering problems; Iden- } \\
\text { tify \& produce need-specific solutions }\end{array}$ & $\begin{array}{l}\text { Videos, reading, assignments, quizzes, tests, etc. } \\
\text { are all available to students to work at their own } \\
\text { pace and in their own time with distinct learning } \\
\text { objectives listed }\end{array}$ \\
\hline $\begin{array}{l}\text { Course modules are } \\
\text { regularly updated for } \\
\text { most recent content }\end{array}$ & $\begin{array}{l}\text { Active- } \\
\text { learn- } \\
\text { ing }\end{array}$ & $\begin{array}{l}\text { Consider impact of solutions in global context; } \\
\text { Function effectively on a team; Effective } \\
\text { communication }\end{array}$ & $\begin{array}{l}\text { Most background readings are in the form of recent } \\
\text { scientific articles that require analytical interpre- } \\
\text { tation of data and demonstrate application of } \\
\text { laboratory techniques }\end{array}$ \\
\hline $\begin{array}{l}\text { Graduate-level home- } \\
\text { work provides real lab } \\
\text { data }\end{array}$ & $\begin{array}{l}\text { Active- } \\
\text { learn- } \\
\text { ing }\end{array}$ & $\begin{array}{l}\text { Develop experimentation; Analyze \& interpret } \\
\text { data; Draw conclusions }\end{array}$ & $\begin{array}{l}\text { Students encounter the messiness of real lab data } \\
\text { and need to analyze and report findings in context }\end{array}$ \\
\hline $\begin{array}{l}\text { Graduate-level content } \\
\text { focuses on real-world } \\
\text { applications }\end{array}$ & $\begin{array}{l}\text { Active- } \\
\text { learn- } \\
\text { ing }\end{array}$ & $\begin{array}{l}\text { Acquire \& apply new knowledge; Identify \& } \\
\text { solve complex engineering problems; Iden- } \\
\text { tify \& produce need-specific solutions }\end{array}$ & $\begin{array}{l}\text { Both online courses are geared to preparing stu- } \\
\text { dents to be ready with analytical/technical skills } \\
\text { and applications needed in the field }\end{array}$ \\
\hline
\end{tabular}

*The three ABET Accreditation defined student learning outcomes that most closely match each content type are identified.

We realize other institutions may not have pre-existing online classes. We provide a curated set of resources we personally used in adapting our lab courses (Table 6). By nature of being sourced through academic journals and biotechnology companies, these resources are routinely updated with new publications and advances. We also provide sources for best practices in creating online content with a particular focus in lab-based classes (Fig. S4). While not comprehensive, we find these guidelines a good start for creating and adapting high-quality online content.
How to: Enhance and Implement Real-Time Modifications to Course Content, Structure, Delivery, and Support

Greater instructor support and in situ course corrections were a major benefit of using pre-existing online content. Soliciting regular and routine student feedback was critical during adaptation, enabling improvements in course design and implementation. ${ }^{4}$ This typically only occurs once per course during normal instruction, but we realized more frequent 
TABLE 5. How Lab Course Objectives were met both with traditional in-person and adapted online lab formats.

\begin{tabular}{|c|c|c|}
\hline Lab course objective & Traditional in-person lab & Adapted online lab \\
\hline $\begin{array}{l}\text { Learn sterile laboratory tech- } \\
\text { niques }\end{array}$ & Perform experimental protocol in lab & $\begin{array}{l}\text { Quiz on principles learned from sterile technique training } \\
\text { videos }\end{array}$ \\
\hline $\begin{array}{l}\text { Perform experiments using } \\
\text { cells }\end{array}$ & $\begin{array}{l}\text { Perform experimental protocol in lab; data } \\
\text { collection and analysis }\end{array}$ & $\begin{array}{l}\text { Quiz on videos showing experimental protocol; Data analy- } \\
\text { sis with pre-recorded raw data }\end{array}$ \\
\hline $\begin{array}{l}\text { Read and critically evaluate } \\
\text { current papers }\end{array}$ & Lab reports & Lab reports; Journal club discussion \\
\hline $\begin{array}{l}\text { Write a scientific publication } \\
\text { formatted reports }\end{array}$ & Lab reports & Lab reports \\
\hline
\end{tabular}

student feedback enabled dynamic adjustment to student needs. ${ }^{5-7}$ We surveyed our students through questions posted to Piazza, anonymous Blackboard surveys, and Google Forms surveys at least every other week. We used multiple forms of communication and both formative assessments and anonymous surveys to capture the greatest percentage of student responses, as we observed participation between platforms varied. As we foresee a need for online-only and blended courses in the future, we suggest collecting frequent faculty and student feedback, in addition to evaluating student performance, to support improvements to undergraduate courses.

The first major change to both courses was additional synchronous and asynchronous instructor interaction and support to meet students' academic and emotional needs during this stressful transition to fully online learning. ${ }^{8-10}$ This was offered by appointment and after each module for the CTS course and once a week for the Immunoengineering course. Each course adapted a moderated, online question board (h ttps://piazza.com/) to address simple questions, held open Zoom office hours, and scheduled times for oneon-one meetings.

Many students reported feeling "overwhelmed" or lacking correct "prerequisite courses to understand material" to keep up with content. In fact, student polling data indicated they spent far greater amounts of time than expected on online modules and assignments. During in-person labs, these questions could be quickly addressed with a short class presentation or demonstration. The frequent feedback filled a critical role in determining any gaps in background knowledge. While Immunoengineering students entered with a strong background in molecular biology and handson experience from the in-person Cell \& Tissue Engineering Lab course, the immunology material required additional effort for most. In response, more detailed expectations were given and modules were removed to better distribute student efforts (Table 1). Similarly, students in CTS indicated a need for more background material, prompting additional integration of short, professionally recorded lectures from an EP Cell \& Tissue Engineering course. These were presented alongside links to published video protocols, thus expanding contextual information for each module. When possible, material was provided in downloadready formats (reducing streaming needs) and with clear instructions for use and desired learning goals. In addition, frequent low-stakes quizzes are suggested to enforce student interaction with and understanding of the material. Group projects and regular peer meetings to discuss material and courses supplemented instructional material to provide a community for learning.

Many of our students were taking an online course for the first time. The lack of in-person peer interactions, self-paced content progression, and occasional difficulties with internet access led to increased stress and anxiety in students that instructors would have missed without these surveys. Opportunities for student-student interaction and direct access to content are key elements of laboratory courses and should be optimized as these same elements encourage engagement in online learning.

\section{REFLECTION}

During in-person instruction, laboratory courses provide a perfect opportunity for students to participate in active learning. Courses that leverage adapted content designed specifically with best practices in online instruction retain the self-exploration and confidence-building material key to active learning (Table 3). ${ }^{11,12}$ Specific additional assignments were created for the online format to meet lab course learning objectives (Table 5). Integrating an onlineformat course, like those described herein, with short videos and readings for knowledge transfer was key to achieving the learning objectives.

We argue that the common objective in laboratory courses of 'learning by doing' or 'learning through failure' can be achieved online. To evaluate this 
TABLE 6. These websites encompass a curated list of existing resources, many of which were used in our courses, along with the rationale and intent for each.

\begin{tabular}{|c|c|c|c|}
\hline Resources & Resource description & Example use & Resource Link \\
\hline $\begin{array}{l}\text { JoVE - } \\
\text { Journal of } \\
\text { Visual- } \\
\text { ized } \\
\text { Experi- } \\
\text { ments }\end{array}$ & $\begin{array}{l}\text { Protocols are videotaped such that de- } \\
\text { tailed video use of technical equip- } \\
\text { ment and purposes are detailed }\end{array}$ & $\begin{array}{l}\text { Training of specialized lab equipment } \\
\text { and techniques that would usually } \\
\text { happen within lab setting }\end{array}$ & https://www.jove.com/ \\
\hline $\begin{array}{l}\text { Lab equip- } \\
\text { ment } \\
\text { websites }\end{array}$ & $\begin{array}{l}\text { Many companies which sell major lab } \\
\text { equipment provide videos for how to } \\
\text { properly use equipment }\end{array}$ & $\begin{array}{l}\text { Insert multiple videos from companies to } \\
\text { form example video equipment }\end{array}$ & $\begin{array}{l}\text { https://www.qiagen.com/us/service-an } \\
\text { d-support/learning-hub/videos/ }\end{array}$ \\
\hline $\begin{array}{l}\text { Prepared } \\
\text { Lab Sim- } \\
\text { ulations }\end{array}$ & $\begin{array}{l}\text { Many laboratories have already devel- } \\
\text { oped outreach simulations or interac- } \\
\text { tive demonstrations of research } \\
\text { related concepts }\end{array}$ & $\begin{array}{l}\text { Replace given lab class with pre-exist- } \\
\text { ing online concept or simulation }\end{array}$ & $\begin{array}{l}\text { https://www.biointeractive.org/classroo } \\
\text { m-resources, https://www.merlot.org/ } \\
\text { merlot/index.htm, }\end{array}$ \\
\hline $\begin{array}{l}\text { Textbook- } \\
\text { sourced } \\
\text { videos }\end{array}$ & $\begin{array}{l}\text { Many textbooks that correspond to } \\
\text { classes will include videos that align } \\
\text { with content delivered and can be } \\
\text { used by teachers in the classroom }\end{array}$ & $\begin{array}{l}\text { Provide introductory material already } \\
\text { formatted into video format }\end{array}$ & $\begin{array}{l}\text { https://wwnorton.com/books/97808153 } \\
45053\end{array}$ \\
\hline $\begin{array}{l}\text { Khan Acad- } \\
\text { emy }\end{array}$ & $\begin{array}{l}\text { Online videos covering most basic } \\
\text { school-based content (e.g. linear } \\
\text { algebra, immunology) }\end{array}$ & $\begin{array}{l}\text { Use to provide basic background infor- } \\
\text { mation before diving into course- } \\
\text { specific content. Very useful for } \\
\text { leveling base student comprehension } \\
\text { from a wide variety of backgrounds }\end{array}$ & https://www.khanacademy.org/ \\
\hline $\begin{array}{l}\text { Nature \& } \\
\text { Science } \\
\text { Podcasts }\end{array}$ & $\begin{array}{l}\text { Podcasts surrounding current scientific } \\
\text { issues/problems and how current } \\
\text { research is being applied to solve } \\
\text { these issues }\end{array}$ & $\begin{array}{l}\text { Demonstrate example of research } \\
\text { applied and see conflicting opinions of } \\
\text { researchers on results from scientific } \\
\text { studies }\end{array}$ & $\begin{array}{l}\text { https://www.sciencemag.org/podcasts, } \\
\text { https://www.nature.com/nature/pod } \\
\text { cast, https://www.nature.com/nbt/arti } \\
\text { cles?type=first-rounders-podcast, }\end{array}$ \\
\hline PhET & $\begin{array}{l}\text { Interactive simulations for Physics, } \\
\text { Chemistry, Math, Biology, and Earth } \\
\text { Science }\end{array}$ & $\begin{array}{l}\text { Allow students to make hypotheses, } \\
\text { vary parameters, observe results }\end{array}$ & https://phet.colorado.edu/ \\
\hline LabXchange & $\begin{array}{l}\text { Learners can design experiments and } \\
\text { execute protocols online using inter- } \\
\text { active simulations of key techniques } \\
\text { in molecular and cellular biology }\end{array}$ & $\begin{array}{l}\text { Simulations for micropipette, gel elec- } \\
\text { trophoresis, cutting up DNA with a } \\
\text { restriction enzyme, etc }\end{array}$ & https://www.labxchange.org/explore \\
\hline TED talks & $\begin{array}{l}\text { Pre-recorded talks ( } \sim 15-20 \text { minutes) } \\
\text { with some demonstrations of innova- } \\
\text { tions and ideas }\end{array}$ & $\begin{array}{l}\text { Useful in stimulating thought and dis- } \\
\text { cussion in online discussion forums } \\
\text { for creating online community }\end{array}$ & https://www.ted.com/talks \\
\hline $\begin{array}{l}\text { Citizen Sci- } \\
\text { ence Pro- } \\
\text { jects }\end{array}$ & $\begin{array}{l}\text { Many scientific endeavors require par- } \\
\text { ticipation of non-scientists and have } \\
\text { set up collaboration/crowd-sourcing } \\
\text { lab campaigns }\end{array}$ & $\begin{array}{l}\text { These could help replace a lab/experi- } \\
\text { ment, by still enabling data collec- } \\
\text { tion/analysis/report from homes of } \\
\text { individual }\end{array}$ & https://www.zooniverse.org/projects \\
\hline
\end{tabular}

These online materials can readily be leveraged by instructors at other institutions in creating BME laboratory-based classes online.

hypothesis, upon return to campus we plan to compare students from the online and in-person courses. We will directly assess student abilities and understanding of core learning objectives. Specifically, we will test mastery using course topic tests, methodology comprehension (what procedural step comes next?), protocol implementation (can student generate data meeting expected results?), and interpreting data from unfamiliar protocols. We simulated typical 'hands-on experiences' with scientific data in the online lab by providing previously generated raw data, so we expect online students will meet or exceed in-person student learning on comprehension, data interpretation, and content quizzes. Without any hands-on experience, we expect online students to indicate more difficulty in performing a new protocol or successful completion of experiment; though, this deficit has been shown to be lower than commonly predicted. ${ }^{2}$

We suggest regular, active sampling of students' 'temperature' through additional surveys and emails on a weekly basis. This level of contact was possible due to having prepared online content. Survey data provided an early notification system permitting rapid responses to difficulties like high workloads and stress levels to master expected content (Table 2). In addition to providing direction to course corrections, these polls revealed student satisfaction with discussion board posts, flexibility of learning at their own pace, and rigor of course material. Final course reflection surveys indicated that undergraduates in Immunoengineering 
felt class difficulty and effort were appropriate and unchanged compared to either in-person or Master's students (Fig. 2a). Undergraduates in the CTS course also reported appropriate effort and difficulty. While there is a decrease in perceived effort, we cannot separate this change from the school-wide switch to "passfail" grading from a traditional scale (Fig. 2b). Consequently, we did not feel direct grade comparisons between in-person and virtual lab courses were appropriate given pandemic situations. Content changes and clarifying course expectations in email announcements were of great assistance to controlling difficulty and effort mid-course but would not have occurred without surveying the unique class needs.

By semester end both courses had separately arrived at a common weekly effort, a routine communication level with students, and found a few common areas to improve in future course offerings. Based upon faculty observations from assignments we see a need for improved student understanding and student responses indicated learning objectives could be more specific and direct. We suggest and will implement the following to address these items:

1. Outlining course learning objectives into a key take-aways/concepts document to review without having to re-watch lecture videos

2. Integrating further group work or small group discussion to foster collaborative learning

3. Implementing socially interactive online tools, like Perusall, ${ }^{13}$ to work through literature in groups permitting students to learn from and teach each other

4. Using effective student-teacher technologies as featured in the JHU Center for Educational Resources Innovative Instructor articles like Slack or Tcrunch (h ttps://cer.jhu.edu/ii/index) and on the JHU EP website for faculty (https://ep.jhu.edu/faculty)

Leveraging self-paced online content provides an optimal blended format for knowledge transfer during future in-person labs. There are several advantages to this hybrid option: it allows both students and faculty to keep socially distant, allows students to focus oncampus time on research and design activities, maintains the high-level of rigor required in course design, and allows resources to be easily shared within the university. As a result of these course successes, the BME undergraduate program is allowing students to take JHU EP courses as a full-semester option and alongside traditional courses. While online courses cannot replicate a hands-on experiment with living cells, nearly all other student learning outcomes are met with online learning, a possible format until the current COVID-19 pandemic subsides.
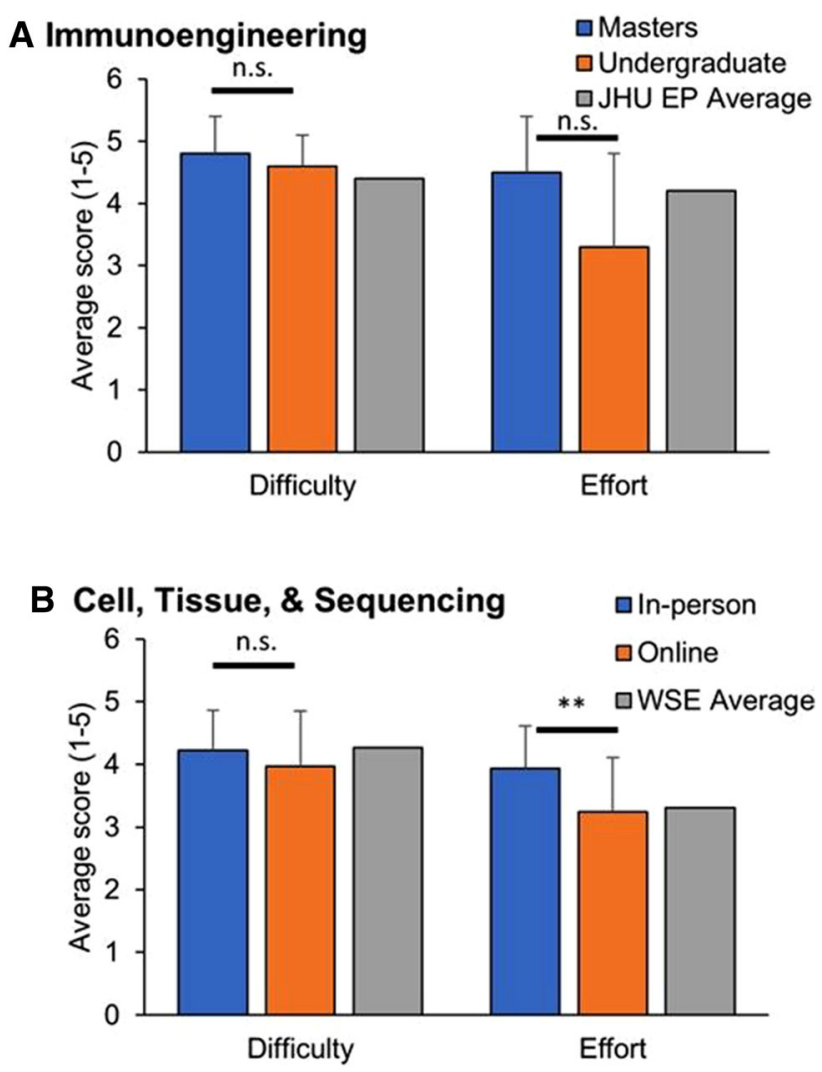

FIGURE 2. Perception of difficulty and level of effort required in traditional and adapted courses. a Students within JHU EP courses are prompted: The course content challenged me (Difficulty) and The course workload requirements were reasonable (Effort) and to rate on a scale from 1 to 5 where these corresponded to the following responses: strongly disagree (1); disagree (2); neutral (3); agree (4); and strongly agree (5). Data represents averages from Immunoengineering Masters level (blue, $n=13 / 13$ ), undergraduate adapted (orange, $n=8 / 27$ ), and JHU EP general course average (grey, school-wide $>100$ ) (error bars denote standard deviation and n.s. denotes not significant when compared with a $t$-test calculated with unequal variance). b Undergraduate student responses to prompts (different than those of the EP survey) were regarding the intellectual challenge and relative workload on a scale of 1 to 5 , with 1 being "far less" and 5 being "far greater." Data represent polling from 73 students registered in Spring 2020, with Traditional Instruction (blue, $\boldsymbol{n}=\mathbf{2 8}$ ), Online Adapted (orange, $n=45$ ), and Whiting School of Engineering (WSE) average (grey) responses (school-wide >100) (error bars denote standard deviation, n.s. not significant when compared with a $t$-test calculated with unequal variance, ${ }^{* *}$ significance when compared with a $t$-test calculated with unequal variance $p<0.01$ ).

\section{ELECTRONIC SUPPLEMENTARY MATERIAL}

The online version of this article (https://doi.org/10. 1007/s43683-020-00041-w) contains supplementary material, which is available to authorized users. 


\section{ACKNOWLEDGMENTS}

Authors acknowledge support from JHU Whiting School of Engineering and JHU Engineering for Professionals programs.

\section{FUNDING}

Not applicable

\section{CONFLICT OF INTEREST}

Authors declare that they have no conflict of interest.

\section{REFERENCES}

\footnotetext{
${ }^{1}$ ABET Student Outcomes: https://www.abet.org/accredita tion/accreditation-criteria/criteria-for-accrediting-engineeri ng-programs-2019-2020/\#GC3.

${ }^{2}$ Bourne J, Harris D, Mayadas F. Online engineering education: Learning anywhere, anytime. J Eng Educ. 2005;94:131-46.

${ }^{3}$ Brickman P, Gormally C, Martella AM. Making the grade: Using instructional feedback and evaluation to inspire evidence-based teaching. CBE. 2016;15:75. https://doi.org/ $10.1187 /$ cbe. $15-12-0249$.

${ }^{4}$ Brinson JR. A further characterization of empirical research related to earning outcome achievement in remote and virtual science labs. J Sci Educ Technol. 2017;26:54660. https://doi.org/10.1007/s10956-017-9699-8.

${ }^{5}$ Coleman SK, Smith CL. Evaluating the benefits of virtual training for bioscience students. High Educ Pedag.
}

2019;4:287-99. https://doi.org/10.1080/23752696.2019.159 9689.

${ }^{6}$ Dziech BW (2020) Students are among the most severe and overlooked victims of the pandemic. Inside Higher Ed. h ttps://www.insidehighered.com/views/2020/04/09/studentsare-among-mostsevere-and-overlooked-victims-pandemicopinion.

${ }^{7}$ Kafka AC (2020) Shock, fear, and fatalism: as coronavirus prompts colleges to close, students grapple with uncertainty. https://www.chronicle.com/article/Shock-FearFata lism-As $/ 248240$.

${ }^{8}$ Lee SC, Yeong FM. Fostering student engagement using online, collaborative reading assignments mediated by Perusall. Asia Pac Sch. 2018;3:46-8.

${ }^{9}$ Nicol D, Macfarlane DD. Formative assessment and selfregulated learning: A model and seven principles of good feedback practice. Stud Higher Educ. 2006;31(2):199-218. https://doi.org/10.1080/03075070600572090.

${ }^{10}$ Nicol DJ, Macfarlane-Dick D. Formative assessment and self-regulated learning: a model and seven principles of good feedback practice. Stud High Educ. 2006;31:199-218. https://doi.org/10.1080/03075070600572090.

${ }^{11}$ Reeves, J., \& Arnold, B. (2015), Applying Student Engagement Techniques to Multidisciplinary Online Engineering Laboratories https://peer.asee.org/23568.

${ }^{12}$ Rolfe I, McPherson J. Formative assessment: How am I doing? Lancet. 1995;345:837-9. https://doi.org/10.1016/S0 140-6736(95)92968-1.

${ }^{13}$ Zacharia ZC, Olympiou G. Physical versus virtual manipulative experimentation in physics learning. Learn Instr. 2011;21(3):317-31. https://doi.org/10.1016/j.learninstruc.2 010.03.001.

Publisher's Note Springer Nature remains neutral with regard to jurisdictional claims in published maps and institutional affiliations. 